\title{
Investigation of Influence Factors on Agricultural Eneterprises Technological Processes Management
}

\author{
Larysa Batiuk \\ Department of Economics and \\ Marketing \\ Kharkiv Petro Vasylenko National \\ Technical University of Agriculture \\ Kharkiv, Ukraine \\ http://orcid.org/0000-0003-3597-860X
}

\author{
Nataliia Birchenko \\ Department of Accounting and Audit \\ Kharkiv Petro Vasylenko National \\ Technical University of Agriculture \\ Kharkiv, Ukraine \\ nabirchenko@ukr.net \\ Liudmyla Polyvana \\ Department of Accounting and Audit \\ V.N. Karazin Kharkiv University \\ Kharkiv, Ukraine \\ L.A.Polyvana@gmail.com \\ http://orcid.org/0000-0003-1204-9218
}

\author{
Olena Lutsenko \\ Department of Accounting and Audit \\ Kharkiv Petro Vasylenko National \\ Technical University of Agriculture \\ Kharkiv, Ukraine \\ http://orcid.org/0000-0002-7991-079X
}

\begin{abstract}
The state of activity of agro-industrial complex (AIC) enterprises in the context of its components is investigated, on the basis of the analyses of changes in the main indicators of agricultural production, the complicate aspects of innovation activity of Ukraine in the agricultural market are identified, the components of technological processes of agricultural production of Ukraine are determined, the factors of influence of agricultural production are investigated on the basis of methods of descriptive statistics management of technological processes of the activity of AIC enterprises.
\end{abstract}

Keywords-technological processes, agro-industrial complex enterprises, agricultural products, risks of agro-industrial production.

\section{INTRODUCTION}

It should be noted that the ability to effectively operate AIC enterprises is a potential property, which requires some efforts, as well as financial and technological means. In today's economic conditions of Ukraine, increasing the efficiency of production at a particular enterprise can be achieved mainly through the implementation and use of innovative technologies in the production of new types of competitive products and their effective management. The functioning of agribusinesses requires the application of new management principles with account of the technical and economic characteristics of technological processes, adapted to the conditions of operation of these enterprises. It is still necessary check the account the level of demand in the relevant markets; pricing strategy; effective methods of dissemination and promotion of innovative products.

Thus, it is possible to conclude that under the current conditions of the agribusiness enterprises, their effective management requires the creation of special approaches, the use of appropriate mathematical and software information tools [1] - [5]. Defined means will allow to substantiate managerial decisions on development and management of enterprises for the production or processing of raw materials in agricultural processes, to determine planned production volumes of innovative products, the degree of effectiveness of introduction of new technological processes in production in strategic and tactical planning of agro-enterprises [6] [10]. The development and implementation of new ones, the refinement and improvement of existing approaches to the control of technological processes with the use of economic and mathematical modelling as the same information technologies, create the preconditions for enterprises to become processes of reproduction and give an additional impetus for innovative development and economic growth [8] $-[11]$.

Analysis of technological innovation management is characterized by the creation, development and dissemination of innovation. Until now, the concept of "innovation" has attracted considerable interest from scientists around the world. Initially, American and European scholars as I. Perlaki [12], E. Rogers [13], B. Santo [14], B. Twiss [15], J. Schumpeter [16] and others. In the domestic literature, the concept of "innovation" began to be used later, although abroad this concept originated in the early XX century. in. During this period, the nature of innovation was more widely explored.

According to the scientific literature, the interest in the development and management of innovations in the world has grown a lot over the last some years/ It was attracted the attention of managers and scientists [17] - [20]. The emergence of new approaches to innovations based on the application of advances in information and communication technologies has catalyzed the dissemination of innovative technologies, innovative products and other elements of IP. Scientists S. Zott, R. Amit, and L. Massa [18] have become the developers and distributors of the concept of business modeling innovation through online resources. D.J. Teece notes that business modeling by innovation is an integral part of the economic behavior of the entity [19].

\section{The Presentation of the Main MAterial}

In order to analyze certain types of factors influencing the activities of AIC enterprises in order to further take these into account in the economic-mathematical model of 
agricultural enterprises technological processes management (AETPM), the dynamics of the main indicators affecting the production of agricultural enterprises, a fragment of which is presented in the Table 1.

TABLE 1 - THE MAIN STATISTICAL CHARACTERISTICS OF THE DISTRIBUTION OF SPECIES RAW MATERIALS FOR ANIMAL HUSBANDRY

\begin{tabular}{|l|c|c|c|c|c|c|c|c|}
\hline Indicator & $y_{1}$ & $y_{2}$ & $y_{3}$ & $y_{4}$ & $y_{5}$ & $y_{6}$ & $y_{7}$ & $y_{8}$ \\
\hline Average & 1078,9 & 363,22 & 846,89 & 95,714 & 592,82 & 175,28 & 1925,5 & 12291 \\
\hline Median & 1074,5 & 337,94 & 839,1 & 75,19 & 587,37 & 169,3 & 1911,7 & 11761 \\
\hline $\begin{array}{l}\text { Dispersio } \\
\text { n }\end{array}$ & 25377 & 5813,6 & 11361 & 3136,8 & 5566,5 & 588,98 & 65740 & 1,1671 \\
\hline $\begin{array}{l}\text { Stand.dev } \\
\text { iation }\end{array}$ & 159,30 & 76,247 & 106,58 & 56,007 & 74,60 & 24,269 & 256,39 & 1080,3 \\
\hline $\begin{array}{l}\text { Koef. of } \\
\text { variat. } \\
\text { (\%) }\end{array}$ & 14,76 & 20,99 & 12,58 & 58,51 & 12,58 & 13,84 & 13,31 & 8,789 \\
\hline $\begin{array}{l}\text { Standard. } \\
\text { error }\end{array}$ & 48,031 & 22,989 & 32,137 & 16,886 & 22,495 & 7,3173 & 77,307 & 325,73 \\
\hline $\begin{array}{l}\text { Mini- } \\
\text { mum }\end{array}$ & 888,46 & 270,61 & 688,71 & 34,86 & 482,1 & 142,4 & 1597,0 & 11086 \\
\hline $\begin{array}{l}\text { Maxi- } \\
\text { mum }\end{array}$ & 1313,7 & 531,33 & 1075,7 & 196,02 & 753,0 & 214,1 & 2389,4 & 13714 \\
\hline Range & 425,22 & 260,72 & 387,01 & 161,16 & 270,9 & 71,7 & 792,4 & 2628,4 \\
\hline $\begin{array}{l}\text { Lower } \\
\text { quartile }\end{array}$ & 908,29 & 318,22 & 761,59 & 40,78 & 533,12 & 152,8 & 1723,2 & 11377 \\
\hline $\begin{array}{l}\text { Upper } \\
\text { quartile }\end{array}$ & 1255,1 & 398,22 & 891,65 & 148,8 & 624,15 & 200,8 & 2143,8 & 13661 \\
\hline $\begin{array}{l}\text { Stand. } \\
\text { asymetr. }\end{array}$ & 0,351 & 1,804 & 0,749 & 0,655 & 0,749 & 0,355 & 0,481 & 0,6114 \\
\hline $\begin{array}{l}\text { Stand. } \\
\text { excess }\end{array}$ & $-0,975$ & 0,930 & 0,831 & $-0,795$ & 0,831 & $-0,856$ & $-0,476$ & $-1,239$ \\
\hline
\end{tabular}

A statistical analysis of the main components of the production process by processing enterprises generating risks (30 indicators) affecting the production of products by agroenterprises was performed and the numerical characteristics of the distribution of their values were calculated.

The basic types of agricultural enterprises' products and the main types of raw materials for the production of these products are investigated on the basis of data for the period 2010 - 2018 by monthly breakdown: products made on the basis of animal husbandry; products made on the basis of vegetable raw materials; products made on the basis of mixed raw materials of husbandry crop and animal production; products from other types of agricultural raw materials (ARMs) [2].

The main products of the first group are beef and veal, fresh (steamed) or chilled, beef and veal, frozen, fresh pork (steamed) or chilled, frozen pork, meat and offal of poultry (fresh or chilled), $\mathrm{m}$ ' edible meat and poultry by-products (frozen), sausage products, processed milk, butter, unfermented and fermented cheese, fatty cheeses, dairy products, etc. The main raw materials for these products are cattle (steam) for steamed or chilled meat $\left(y_{1}\right)$, cattle for frozen meat (cows) $\left(y_{2}\right)$, pigs for steamed or chilled meat $\left(y_{3}\right)$, pigs for frozen meat $\left(y_{4}\right)$, poultry for fresh or chilled meat $\left(y_{5}\right)$, poultry for meat and by-products of poultry (frozen) $\left(y_{6}\right)$, meat (in slaughterhouse) $\left(y_{7}\right)$, milk $\left(y_{8}\right)$.

On the basis of the conducted analysis, the numerical characteristics of the distribution of values of the volumes of products from livestock raw materials and the volumes of their origin for these products were found (Table 2).
TABLE 2 - LIVESTOCK AND POULTRY LIVESTOCK AS OF JANUARY 1, 2018, THOUS. HEADS

\begin{tabular}{|c|c|c|c|c|}
\hline $\begin{array}{c}\text { Cattle, } \\
\text { total }\end{array}$ & $\begin{array}{l}\text { Cattle, } \\
\text { including } \\
\text { cows }\end{array}$ & Pigs & $\begin{array}{c}\text { Sheep } \\
\text { and } \\
\text { goats }\end{array}$ & $\begin{array}{c}\text { Bird, } 100 \\
\text { thousand } \\
\text { heads }\end{array}$ \\
\hline 25195 & 8527,6 & 19947 & 9003,1 & 255,1 \\
\hline 24623 & 8378,2 & 19427 & 8418,7 & 246,1 \\
\hline 23728 & 8262,6 & 17839 & 7829,1 & 243,1 \\
\hline 22457 & 8057,2 & 16175 & 7236,6 & 214,6 \\
\hline 21607 & 8077,7 & 15298 & 6862,6 & 190,5 \\
\hline 19624 & 7818,3 & 13946 & 5574,5 & 164,9 \\
\hline 17557 & 7531,3 & 13144 & 4098,6 & 149,7 \\
\hline 15313 & 6971,9 & 11236 & 3047,1 & 129,4 \\
\hline 12759 & 6264,8 & 9478,7 & 2361,8 & 123,3 \\
\hline 11722 & 5840,8 & 10083 & 2026 & 129,5 \\
\hline 10627 & 5431 & 10073 & 1884,7 & 126,1 \\
\hline 9423,7 & 4958,3 & 7652,3 & 1875 & 123,7 \\
\hline 9421,1 & 4918,1 & 8369,5 & 1965 & 136,8 \\
\hline 9108,4 & 4715,6 & 9203,7 & 1984,4 & 147,4 \\
\hline 7712,1 & 4283,5 & 7321,5 & 1858,8 & 142,4 \\
\hline 6902,9 & 3926 & 6466,1 & 1754,5 & 152,8 \\
\hline 6514,1 & 3635,1 & 7052,8 & 1629,5 & 162 \\
\hline 6175,4 & 3346,7 & 8055 & 1617,2 & 166,5 \\
\hline 5490,9 & 3095,9 & 7019,9 & 1678,6 & 169,3 \\
\hline 5079 & 2856,3 & 6526 & 1726,9 & 177,6 \\
\hline 4826,7 & 2736,5 & 7576,6 & 1832,5 & 191,4 \\
\hline 4494,4 & 2631,2 & 7960,4 & 1731,7 & 203,8 \\
\hline 4425,8 & 2582,2 & 7373,2 & 1739,4 & 200,8 \\
\hline 4645,9 & 2554,3 & 7576,7 & 1738,2 & 214,1 \\
\hline
\end{tabular}

The main products made on the basis of vegetable raw materials include: sunflower oil, flour, cereals, white crystalline sugar, non-denatured ethyl alcohol with an alcohol content of at least $80 \%$ vol.

The main plant resources for these products are sunflower seeds $\left(y_{1}\right)$, cereals and legumes $\left(y_{2}\right)$, oilseeds $\left(y_{3}\right)$, sugar beets $\left(y_{4}\right)$. Based on the analysis, their main statistical characteristics were found (Table 3).

Similar calculations are also made for products made from mixed raw materials. These products include: spreads and mixtures of fat, bakery products, margarine and similar products, biscuits and waffles, pasta without stuffing, not cooked or otherwise prepared, pasta stuffed, cooked or otherwise prepared (dried, frozen): ravioli, dumplings, etc.; couscous, confectionery made of sugar (including white chocolate), not containing cocoa and others. Raw materials of vegetable and animal origin are used for these products: cereals and legumes, eggs from poultry, sugar beets, sunflower seeds, milk, meat, oilseeds, etc.

Products from other raw materials include natural juices, including concentrated, blended natural juices, vodka, other spirits (drinking alcohol with an alcohol content of less than 
45.4 vol.\%; Alcohols obtained by distillation from fruits other than liqueurs, gin, wine grape), cotton yarn, etc. the ARMs for them are fruits and berries for fermentation, and for yarn it is wool.

TABLE 3 - THE MAIN STATISTICAL CHARACTERISTICS OF THE DISTRIBUTION OF SPECIES RAW MATERIALS OF PLANT GROWING

\begin{tabular}{|c|c|c|c|c|}
\hline \multirow[t]{3}{*}{ Indicator } & \multicolumn{4}{|c|}{$\begin{array}{c}\text { Emissions from stationary } \\
\text { sources of pollution }\end{array}$} \\
\hline & \multicolumn{2}{|c|}{ pollutants } & \multicolumn{2}{|c|}{ carbon dioxide } \\
\hline & thous. $t$. & $\%$ to the total & thous. $t$. & $\begin{array}{c}\% \text { to the } \\
\text { total }\end{array}$ \\
\hline $\begin{array}{l}\text { All types of economic } \\
\text { activity }\end{array}$ & 4295,1 & 100,0 & 197618,0 & 100 \\
\hline $\begin{array}{l}\text { of them } \\
\text { mining and quarrying }\end{array}$ & 921,2 & 21,4 & 4282,4 & 2,2 \\
\hline $\begin{array}{l}\text { manufacturing industry } \\
\text { including }\end{array}$ & 1230,9 & 28,7 & 82082,6 & 41,5 \\
\hline $\begin{array}{l}\text { including manufacture } \\
\text { of food, beverages and } \\
\text { tobacco }\end{array}$ & 21,9 & 0,5 & 2041,2 & 1 \\
\hline $\begin{array}{l}\text { production of coke } \\
\text { and products }\end{array}$ & 66,4 & 1,5 & 4823,8 & 2,4 \\
\hline oil refining & 38,8 & 0,9 & 4941,5 & 2,5 \\
\hline metallurgical production & 1004,6 & 23,4 & 60520,6 & 30,6 \\
\hline $\begin{array}{l}\text { supply of gas, } \\
\text { electricity, steam and air } \\
\text { conditioning }\end{array}$ & 1838,9 & 42,8 & 104413,6 & 52,8 \\
\hline $\begin{array}{l}\text { transport, warehousing, } \\
\text { postal and courier } \\
\text { activities }\end{array}$ & 166,5 & 3,9 & 4332,6 & 2,2 \\
\hline $\begin{array}{l}\text { technological processes } \\
\text { in mechanical } \\
\text { engineering, } \\
\text { woodworking, pulp and } \\
\text { paper and food industry } \\
\text { and in other sectors }\end{array}$ & 3,943 & 57858,6 & 1,3 & 14,7 \\
\hline bread industry & 0,232 & 2616,4 & 0,1 & 11,3 \\
\hline wine production & 0,025 & 94,9 & 0 & 3,8 \\
\hline beer production & 0,029 & 101,4 & 0 & 3,5 \\
\hline $\begin{array}{l}\text { production of strong } \\
\text { alcoholic beverages }\end{array}$ & 0,026 & 371,5 & 0 & 14,3 \\
\hline other food industries & 0,429 & 7479,6 & 0,2 & 17,4 \\
\hline
\end{tabular}

Similar calculations of statistical analysis have been made for the main components that support the production process of AIC enterprises. By means of the analysis the average values of the volumes of raw materials, their maximum and minimum values, the median, the quadratic error, etc. are determined. Given the values of the medians and standard errors, the level of risk was justified. The calculated values make it possible to state the impact of the risks associated with the main components of the production of agricultural products of the agroindustrial complex and give the basis for their use in the model of AETPM.

Thus, the system of partial risk-determining indicators includes: production volumes of products of different types, volumes of ARMs of different types, volumes of consumed electricity and energy capacities of enterprises, prices of ARMs of different types, prices of basic products of production of agricultural enterprises prices for water, electricity, gas and other fuels, inflation index, bank discount rate.

It is well known that the environmental factor and the associated environmental risks can have a significant impact on the production of agro-industrial processes [21]. Let us investigate the risks of environmental pollution in agricultural production within Ukraine. Consider the structure of pollutant emissions across the country's industry, its agrarian sector, and the industry involved in the production and processing of ARMs. The main air pollutants in 2018 were processing and extractive industries (29\% and $21 \%$ of harmful emissions respectively) and gas, electricity, steam and air conditioning (43\%), as evidenced by such data (Table 4).

TABLE 4 - EMISSIONS FROM STATIONARY SOURCES OF POLLUTION BY TYPE OF ECONOMIC ACTIVITY

\begin{tabular}{|l|l|l|l|l|}
\hline Indicator & \multicolumn{1}{|c|}{$y_{1}$} & \multicolumn{1}{c|}{$y_{2}$} & \multicolumn{1}{c|}{$y_{3}$} & \multicolumn{1}{c|}{$y_{4}$} \\
\hline Average & 6298,09 & 42565,0 & 879,482 & 15462,0 \\
\hline Median & 6364,0 & 41809,0 & 799,0 & 15468,0 \\
\hline Dispersion & $5,5589 \mathrm{E} 6$ & 40746,9 & 798,221 & 15066,0 \\
\hline $\begin{array}{l}\text { Standard. } \\
\text { deviation }\end{array}$ & 2357,73 & 12397,7 & 398,802 & 3658,92 \\
\hline $\begin{array}{l}\text { oefficient of } \\
\text { variation }\end{array}$ & $37,4357 \%$ & $29,1266 \%$ & $45,3451 \%$ & $23,6639 \%$ \\
\hline $\begin{array}{l}\text { Standard } \\
\text { error }\end{array}$ & 710,883 & 3738,06 & 120,243 & 1103,21 \\
\hline Minimum & 3050,0 & 20234,0 & 417,8 & 10068,0 \\
\hline Maximum & 11051,0 & 63051,0 & 1547,1 & 22421,0 \\
\hline Range & 8001,0 & 42817,0 & 1129,3 & 12353,0 \\
\hline $\begin{array}{l}\text { Lower } \\
\text { quartile }\end{array}$ & 4254,0 & 34258,0 & 515,2 & 13392,0 \\
\hline $\begin{array}{l}\text { The upper } \\
\text { quartile }\end{array}$ & 8387,0 & 53290,0 & 1299,8 & 18439,0 \\
\hline $\begin{array}{l}\text { Standard. } \\
\text { asymmetry }\end{array}$ & 0,9168 & $-0,1218$ & 0,6268 & 0,4135 \\
\hline $\begin{array}{l}\text { Standard. } \\
\text { excess }\end{array}$ & 0,0613 & $-0,1146$ & $-0,8410$ & $-0,1109$ \\
\hline
\end{tabular}

The analysis of the data for the last years (2009-2018) showed that the content of processing industry emissions in the country's industry is $29.18 \%$ on average, and of the AIC average $1.97 \%$ of the total amount of pollutants within the industry of Ukraine.

Let us consider the impact on the ecology of emissions of harmful substances of agricultural enterprises of the Kharkiv region. Based on the analysis of the volume of pollutant emissions into the atmosphere from stationary sources of pollution in 2018 , the analysis of their content in the volume of all enterprises in Kharkiv region and its agricultural enterprises was carried out.

It is found that in 2018 city and region agro-enterprises produced 1926,601 tons of pollutant emissions, which is $0.975 \%$ of the emissions of all enterprises in the region (197601,175 tones). In turn, the emissions of all agricultural enterprises from the total volume of enterprises in the region averaged $0.0519 \%$. This indicates a rather small impact of the activities of agricultural enterprises on the environmental status of the environment [22, 23]. Thus, the performed analysis on the example of the enterprises of Kharkiv region gives reason to disregard environmental risks in the general list of risks of enterprises for the production and processing of ARMs.

\section{CONCLUSIONS}

Thus, it can be concluded that the agro-industrial sector generates a rather small amount of pollutant emissions from its activities and has a relatively small impact on the 
environmental situation as a whole, which indicates the insignificance or absence of environmental risks in the field of agricultural production and gives environmental reasons not to take into account when modeling in UTPA APK.

Thus, on the basis of the theoretical, logical and statistical analysis, the main risk factors that influence the activities of agricultural enterprises are substantiated. It can be concluded that the effect of these risk factors is: the impact on the production of finished products, the resource component used to produce products on the basis of technological innovation, and on financial resources aimed at technological processes. On the basis of the conducted research, a statistical analysis was made and statistical indicators characterizing the level of risks by the main types of products, raw materials used, prices, macroeconomic indicators (change in discount rates, inflation) and other factors of production were made. This gave reason to specify the risks of agricultural enterprises in the implementation of technological processes.

On the basis of the methods of descriptive statistics the basic components that provide the process of production of production by agricultural enterprises are investigated. Based on the performed statistical analysis, the analysis of the calculated numerical characteristics, including the mean values, variances, medians and modes, their deviations, standard errors and variances, coefficients of variation, etc. indicates the heterogeneity, non-uniformity and nonstationarity of the values of these characteristics. The analysis made it possible to substantiate the existence of types of risks associated with the main components of production of agricultural products. The study of the nature of behavior of the main constituents on which the functioning of enterprises depends, has shown considerable difficulties in constructing the law of distribution of these quantities and, as a consequence, determining the level of probabilities of their manifestation and other stochastic characteristics, including. influenced the choice of models from the deterministic class, and the rejection of stochastic models for use in the modeling of UTPA.

Based on the statistical analysis, it is possible to conclude that the system of main partial indicators determining the factors of influence include: volumes of used ARMs of different types, volumes of consumed electricity and energy capacities of enterprises, prices of ARMs of different types, prices of basic agricultural products, prices for water, electricity, gas and other fuels, inflation index, bank discount rate, etc. At the same time, the study of the impact of environmental factors and related environmental risks on agro-industrial production within Ukraine and on the example of the Kharkiv region enterprises shows that the activity of agricultural enterprises on the environmental status of the agricultural sector is rather insignificant. Thus, the performed analysis gives the reason not to take into account the ecological factor and "ecological" risks when modeling in the management of IP of enterprises for production and processing of ARMs.

\section{REFERENCES}

[1] Y., Doz, M., Kosenen, „Embedding strategic agility: A leadership agenda for accelerating business model renewal", Long Range Planning, no. 43, 2010, pp. $370-382$.
[2] V., Babenko, I., Perevozova, O., Mandych, T., Kvyatko, O., Maliy, and I., Mykolenko, "World informatization in conditions of international globalization: factors of influence", Global. J. Environ. $\begin{array}{llll}\text { Sci. } & \text { Manage., } & \text { 5(SI): } & \end{array}$ http://dx.doi.org/10.22034/gjesm.2019.05.SI.19

[3] V.Oliinyk, O. Kozmenko, I. Wiebe, and S. Kozmenko, "Optimal Control over the Process of Innovative Product Diffusion: The Case of Sony Corporation," Economics and Sociology, 11(3), pp. 265-285, 2018. DOI:10.14254/2071- 789X.2018/11-3/16

[4] V., Babenko, Z., Kulczyk, I., Perevosova, O., Syniavska and O., Davydova, Factors of the development of international e-commerce under the conditions of globalization, SHS Web of Conferences, 6. 2019, pp. 10-16. DOI: https://doi.org/10.1051/shsconf/20196504016

[5] I. A., Shumpeter, Teoryia ekonomycheskoho razvytyia, M.: DyrektMedya, 2007, $400 \mathrm{~s}$

[6] N., Vasylieva, "Problems and prospects of food security in Ukraine", Bulgarian Journal of Agricultural Science, vol. 25, no 4, pp. 668676, 2019.

[7] V. O., Babenko, "Modeling of factors influencing innovation activities of agricultural enterprises of Ukraine", Scientific Bulletin of Polissia, no. 1 (9), p. 2, 2017, pp. 115-121. DOI: 10.25140/24109576-2017-2-2(10)- 115-121

[8] N., Vasylieva, "Ukrainian Agricultural Contribution to the World Food Security: Economic Problems and Prospects", Montenegrin Journal of Economics, vol. 14, no. 4, pp. 215-224, 2018. DOI: 10.14254/1800-5845/2018.14-4.15

[9] V., Babenko, V., Sidorov, Y., Koniaieva, and L., Kysliuk, "Features in scientific and technical cooperation in the field of non-conventional renewable energy", Global Journal of Environmental Science and Management, vol. 5 (SI), pp. 105-112, 2019. DOI: http://dx.doi.org/10.22034/gjesm.2019.05.SI.12

[10] M. W., Johnson, Seizing the white space. Business Model Innovation for growth and renewal, Harvard Business Press: Boston, Massachussetts, 2010.

[11] R., Amit, and C., Zott, ,Value Through Business Model Innovation”, MIT Sloan Management Rewiew, 53 (3), 2012, pp. 41 - 49.

[12] D. J., Teece, „Business models, business strategy and innovation", Long Rang Planning, no. 43, 2011, pp. 172 - 194.

[13] A., Blazhei, D., Dryensky, and Y. Perlaki, Nauchno-tekhnycheskaia revoliutsyia y ynzhenernoe obrazovanye: [per. so slovats.]; red. A. Ya. Savelev, M.: Vissh. shk., 1980, 284 s.

[14] E., Rodzhers, and R., Aharvala-Rodzhers, Kommunykatsii v orhanyzatsii, M.: Ekonomyka, 176 s., 1980 [in Russia].

[15] B., Santo, Ynnovatsyia kak sredstvo ekonomycheskoho razvytyia: [per. s venh.]; obshch. red. y vstup. B. V. Sazonova, M.: Prohress, 1990, 296 s. [in Russia]

[16] Braian, Tviss, Upravlenye nauchno-tekhnycheskymy novovvedenyiamy: sokr. per. s anhl.; [predysl. K.F. Puziny]. M.: Ekonomyka, 1989, 271 s. [in Russia].

[17] R. G., McGrath, "Business models: A discovery driven approach", Long Range Planning, № 43, 2010, pp. 247 - 261.

[18] V. O., Babenko, V. O., Petuhova, and A. S., Perepelitsia, "Forming of informatization strategic prospects for Ukraine in conditions of world economy globalization", Scientific Bulletin of Polissia, vol. 1, no. 2 (10), 2017, pp. 24-34. DOI: 10.25140/2410-9576-2017-1-2(10)-24-34

[19] T., Saaty, L, Thomas, Decision Making for Leaders, Pittsburgh: RWS Publications, 1992, 243 p.

[20] L, Malyarets, M., Draskovic, V., Babenko, Z., Kochuyeva, and Dorokhov, O., "Theory and practice of controlling at enterprises in international business", Economic Annals-XXI, vol. 165, iss. 5-6, pp. 90-96, 2017. DOI: https://doi.org/10.21003/ea.V165-19

[21] World economic outlook, April 2014: recovery strengthens, remains uneven, Intern. Monetary Fund, Washington: IMF, XVI, 2014, 216 p.

[22] A.F., Shorikov, and V.A., Babenko, "Optimization of assured result in dynamical model of management of innovation process in the enterprise of agricultural production complex", Economy of Region, iss. 1, 2014, pp. 196-202. DOI: 10.17059/2014-1-18

R., Casadesus-Masanell, and J. E., Ricart., "From strategy to business models and to tactics", Long Range Planning, 43, 2010, pp. 195 215 . 